\title{
Correlation between optic nerve sheath diameter and Rotterdam computer tomography scoring in pediatric brain injury
}

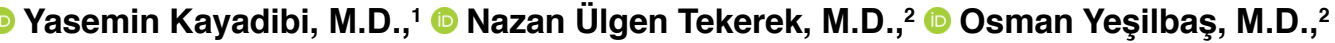 \\ (D) Serhat Tekerek, M.D., ${ }^{1}$ () Emel Üre, M.D., ${ }^{3}$ ๑ Turgut Kayadibi, M.D., ${ }^{4}$ \\ (1) Deniz Esin Tekcan Şanlı, M.D. ${ }^{5}$
}

\author{
1Department of Radiology, Van Training and Research Hospital, Van-Turkey \\ 2Department of Pediatric Intensive Care Unit, Van Training and Research Hospital, Van-Turkey \\ ${ }^{3}$ Department of Radiology, Hakkari State Hospital, Hakkari-Turkey \\ ${ }^{4}$ Department of Plastic Surgery, Van Training and Research Hospital, Van-Turkey \\ ${ }^{5}$ Department of Radiology, Kahramanmaraş Necip Fazıl City Hospital, Kahramanmaraş, Turkey
}

\begin{abstract}
BACKGROUND: Pediatric head trauma is the most common presentation to emergency departments. Increased intracranial pressure (ICP) may lead to secondary brain damage in head trauma and early diagnosis of increased ICP is very important. Measurement of optic nerve sheath diameter (ONSD) is a method that can be used for determining increased ICP. In this study, we aimed to evaluate the relationship between optic nerve sheath diameter (ONSD) and Rotterdam computer tomography scores (RCTS) in pediatric patients for severe head trauma.
\end{abstract}

METHODS: During January 2017-April 2018, medical records and imaging findings of children aged 0-18 years who underwent computed tomography $(C T)$ imaging for head trauma $(n=40 \mathrm{l})$ and non-traumatic (convulsions, respiratory disorders, headache) $(n=255)$ complaints, totally 656 patient were evaluated retrospectively. Patients' age, sex, presentation and trauma type (high energy-low energy) were identified. Non-traumatic patients with normal cranial CT findings were considered as the control group. CT findings of traumatic brain injury were scored according to Rotterdam criteria. Patients were divided into groups according to their age as follows: 0-3 years, 3-6 years, 6-12 years and $12-18$ years.

RESULTS: In our study, tomographic reference measurements of the ONSD in pediatric cases were presented according to age. There was a statistically significant difference between ONSD of severe traumatic patients and the control group. Correlation between RCTS and ONSD was determined and age-specific cut-off values of ONSD for severe traumatic scores (score 4-5-6) were presented.

CONCLUSION: In our study, reference ONSDs of the pediatric population for CT imaging was indicated. Our study also showed that ONSD measurement is a parameter that can be used in addition to the RCTS to determine the prognosis of the patient in severe head trauma, by reflecting increased intracranial pressure.

Keywords: Brain edema; intracranial pressure; optic nerve sheath diameter; pediatric head trauma; Rotterdam computer tomography score.

\section{INTRODUCTION}

Head trauma is the most frequent pediatric presentation to emergency departments and the most important cause of pediatric morbidity and mortality. Falling from high and traffic accidents are the most common causes of head trauma. ${ }^{[1,2]}$ Especially in moderate and severe head trauma patients, the role of initial cranial computed tomography $(\mathrm{CT})$ is very

Cite this article as: Kayadibi Y, Ülgen Tekerek N, Yeşilbaş O, Tekerek S, Üre E, Kayadibi T, et al. Correlation between optic nerve sheath diameter (ONSD) and Rotterdam computer tomography scoring in pediatric brain injury. Ulus Travma Acil Cerrahi Derg 2020;26:212-221.

Address for correspondence: Yasemin Kayadibi, M.D.

Van Eğitim ve Araştırma Hastanesi, Radyoloji Kliniği, Van, Turkey

Tel: +90 432 - 4449965 E-mail: ysmnkayadibi@gmail.com

Ulus Travma Acil Cerrahi Derg 2020;26(2):2I2-22I DOI: 10.14744/tjtes.2019.94994 Submitted: 12.09.2018 Accepted: 30.04 .2019 Online: 24.02 .2020

Copyright 2020 Turkish Association of Trauma and Emergency Surgery 
important in diagnosis by its high sensitivity for intracranial bleeding and fractures. ${ }^{[1]}$ Marshall and Rotterdam CT scoring systems, which have numerical values from one to six are the most commonly used two scoring systems to assess the relationship between prognosis and findings of traumatic brain at the first scan. ${ }^{[3]}$ Since the Marshall scoring system does not evaluate epidural and subdural lesions separately and does not include subarachnoid hemorrhage in scoring, the RCTS system is more preferred today. ${ }^{[4]}$ Both of these systems have been created for adult patients and there is a limited number of studies evaluating the prognostic outcome for pediatric patients. ${ }^{[5]}$ There are differences between adult and pediatric brain damage after the injury due to such factors like thickness of the cranium, the ratio of cerebrospinal fluid (CSF)/brain parenchyma, myelination of the brain tissue and mechanism of the trauma. ${ }^{[3,6]}$ While skull fracture, epidural hematoma and axonal damage are frequently encountered in the pediatric patient group, subdural hematomas and midline shifts are more common in the adult group. ${ }^{[3,7]}$

High intracranial pressure (ICP) (above from $20 \mathrm{mmHg}$ ) is one of the most important factors affecting mortality and morbidity after traumatic brain injury and causes secondary damage to the ischemic brain. Early diagnosis and treatment of increased ICP is very important to reduce brain damage after trauma. ${ }^{[8,9]}$ Intraventricular catheter placement is the gold standard method for measuring intracranial pressure. ${ }^{[10]}$ However, it cannot be applicable for every patient in every center due to reasons, such as lack of skilled technical team and equipment, inadequate ventricular width, risk of bleeding. [8-10] Because of these reasons, most emergency departments use $C T$ to investigate increased brain pressure with findings of brain edema. ${ }^{[3, I]}$ On the other hand, optic nerve has direct contact with dura mater and subarachnoid space. In the literature, many studies, both with pediatric and adult patients, have shown that optic nerve sheath diameter (ONSD) has a correlation with ICP and mortality. ${ }^{[8,10,12-17]}$ Although ONSD can be measured with ultrasonography (US), magnetic resonance imaging (MRI) and CT, in the literature, the US examination is more preferred because it does not contain ionizing radiation, reflects instantaneous values and can easily be applied at the bedside in intensive care units. However, there are some disadvantages of the US usage, like person dependence and need of technical expertise to obtain optimal images. Still, there is at least one initial referral CT of serious head trauma patients for determining the severity of the trauma and the necessity for emergency surgery. ONSD can be easily measured using CT and this method could give more objective values. High resolution of MRI facilitates ONSD measurement. However, are disadvantages like the high cost, need of sedation, low sensitivity for bleeding and fractures in the traumatic brain injury. $\mathrm{CT}$ and MRI studies were limited in pediatric population.

In this study, we aimed to investigate the age-related correlation between the ONSD measurements and the Rotterdam $\mathrm{CT}$ scores of initial CT imaging.

\section{MATERIALS AND METHODS}

This study was started in a single-center after the approval from our hospital ethics committee. Pediatric patients who underwent a cranial CT scan for traumatic and non-traumatic reasons (upper respiratory tract infection, headache, convulsions, fever) from January 2017 through April 2018 in the emergency department were included in this study The nontraumatic patient group was determined as a control group. Patients' demographic characteristics (age, sex), trauma patterns (low-energy or high-energy) were retrospectively screened from the medical records of the hospital.

\section{Selection of the Patients and the Control Group}

Criteria of the Patient Group for Acceptance to the Study Patients who admitted to the emergency department for traumatic brain injury and underwent CT imaging within the first 24 hours after the trauma under the age of 18 were included in this study. Patients were excluded if they had facial trauma or artifacts that could affect the optic channel.

\section{Criteria of the Control Group for Acceptance to the Study}

Patients who admitted to the emergency department for non-traumatic reasons (upper respiratory tract infection, headache, convulsions, fever) under the age of 18 were included in this study. Patients were excluded if they had any circumscribing lesion that could affect the intracranial pressure, such as hydrocephalus, tumor, arachnoid cyst or artifacts that affect the optic channel.

\section{Examination of the Head CTs}

Taken initial admission CT images for all included cases were imported into picture archiving and communication system (PACS). Pediatric head CTs were independently reviewed by two different radiologists (YK and ST) to prevent bias. Radiologists were unaware of the patients' age, trauma shape, and Glasgow Coma Score. All the CT scans were obtained by the 16-slice CT scanner (Alexion 16, Toshiba Medical Systems, Tochigi, Japan), a $3 \mathrm{~mm}$ single slice section. Scans of the cranium were displayed using a standard Toshiba mediastinum algorithm at a window level, of 10 and window width of 300 $\mathrm{HU}$. All measurements were made using the same window, contrast and brightness. ONSD was measured as suggested in the literature, posterior to the orbital cortex at a distance of $3 \mathrm{~mm}$ from the optic disc. ${ }^{[14,18]}$

Firstly, measurements were taken from both optical sheaths, and then an average value was obtained for each patient by one of the radiologists. Patients who could not be measured from both eyes were excluded from this study. One of the radiologists evaluated, head CT images, for fracture, hemorrhage (subdural-epidural-subarachnoid-intraventricular), basal cistern compression, herniation, the shift in midline structures and calculated RCTS according to prespecified parameters. ${ }^{[19]}$ 


\section{Statistical Analysis}

Data were statistically analyzed with SPSS 22.0 software (IBM, Armonk, NY). Continuous variables were presented as mean $\pm S D$ or median (with interquartile range), and categorical variables were expressed as numbers and percentages, where appropriate. The comparison between the two groups for data with normal distribution was performed using Student's t-test, and the comparison between groups for data that did not show a normal distribution was performed using the Mann-Whitney $U$ test. Categorical variables were compared using $\chi^{2}$ test. For multigroup comparison, One-way ANOVA (for data showing normal distribution) or Kruskal Wallis (for data which did not show normal distribution) was used. Receiver operating characteristic (ROC) curves were utilized to evaluate the accuracy of optic nerve diameter to diagnose increased ICP. The area under ROC curve (AUC) and cut-off values were compared using MedCalc for Windows, version 9.2 (MedCalc Software, Ostend, Belgium). All probabilities were two-tailed and $p<0.05$ was regarded as significant.

\section{RESULTS}

\section{General and Demographic Data}

Between January 2017 and April 2018, a total of 800 patients admitted to the emergency department and underwent CT imaging. When retrospective CT images were analyzed, 656 of these patients met the inclusion criteria. The summary of the demographic data is shown in Table $I$.

The number of patients considered to have traumatic brain injury (TBI) was $40 \mathrm{I}$ and the number of non -traumatic patient group was 255 . The mean age of TBI patients was 84 months (I-216 months), while the mean age of the control group was 144 months (I-216). One hundred thirty-nine of TBI patients were female, 262 were male, and in the control group, 126 of them were female and 129 were male.

Approximately one-quarter of the patients with TBI $(n=|0|)$ suffered from low-energy trauma (falling, blunt trauma, beating); three quarters $(n=300)$ suffered from high-energy trauma (traffic accidents, and falling from high). The reasons

Table I. The summary of the demographic data and average of the ONSDs

\begin{tabular}{|c|c|c|c|}
\hline & \multicolumn{2}{|c|}{ TBI group $(n=40 I)$} & \multirow[t]{2}{*}{ Control group $(n=255)$} \\
\hline & $\begin{array}{l}\text { Mild trauma (score I-2-3) } \\
\qquad(\mathrm{n}=343)\end{array}$ & $\begin{array}{l}\text { Severe trauma (score 4-5-6) } \\
\qquad(n=57)\end{array}$ & \\
\hline Age, months (min-max) & $100(I-216)$ & $106(1-216)$ & $144(I-2 \mid 6)$ \\
\hline \multicolumn{4}{|l|}{ Gender, n } \\
\hline Girl & 221 & 16 & 126 \\
\hline Boy & 122 & 41 & 129 \\
\hline \multicolumn{4}{|l|}{ Trauma patterns, $\mathrm{n}$} \\
\hline High-speed & 62 & 38 & - \\
\hline Low-speed & 281 & 19 & - \\
\hline \multicolumn{4}{|l|}{ Cephal hematoma, $n$} \\
\hline Present & 51 & 50 & - \\
\hline Absent & 292 & 7 & - \\
\hline \multicolumn{4}{|l|}{ Fracture, $n$} \\
\hline Thin, non-displaced & 78 & 20 & - \\
\hline Multiple, displaced & 22 & 10 & - \\
\hline Absent & 243 & 27 & - \\
\hline \multicolumn{4}{|l|}{ Bleeding, $n$} \\
\hline Present & 132 & 30 & - \\
\hline Absent & 211 & 27 & - \\
\hline \multicolumn{4}{|c|}{ ONSD, mean mm (min-max) } \\
\hline $0-3$ years & $3.6(2.45-5.1)$ & $3.82(2.6-5.6)$ & $3.25(2.15-4.6)$ \\
\hline $3-6$ years & $4(3.05-5.45)$ & $4.34(3.5-5.55)$ & $3.60(2.75-4.45)$ \\
\hline $6-12$ years & $4.04(3.78-6.35)$ & $4.48(3.5-5.8)$ & $3.80(3.15-4.65)$ \\
\hline $12-18$ years & $4.17(3.15-6)$ & $4.84(4.2-7.4)$ & $3.85(3.20-4.95)$ \\
\hline
\end{tabular}

ONSD: Optic nerve sheath diameter. 
for admission to the emergency department in the non-traumatic control group were febrile convulsions (34), headache (140), afebrile convulsions (20), vomiting (16), syncope (6) and upper respiratory tract infection (39).

\section{ONSD Measurements}

Patients and control groups were classified according to range of age 0-3 years, 3-6 years, 6-12 years and $12-18$ years. The mean ONSD values in patients with TBI and the control group were summarized in Table I. According to age groups, ONSD showed a rapid increase in the first three years of age and drew a plateau after six years. There was no significant difference between gender both for the control group and the patient group $(p>0.005)$. We did not find any significant difference between ONSD diameters taken separately for both eyes $(p>0.005)$.

\section{Rotterdam CT Scores}

Of the $40 \mathrm{I}$ patients in the TBI group, 14 of them were scored I; 296 of them scored 2; 32 of them were scored 3; 19 of them were scored 4; 26 of them were scored $5 ; 13$ of them were scored 6 . A total of 342 headache traumas with a score of $1-2-3$ were identified as mild head trauma, and 58 of them with score 4-5-6 were identified as severe head trauma (Fig. I, 2).

\section{Relationship Between Severe Brain Injury and ONSD}

There was a significant correlation between ONSD and severe (RCTS 4-5 and 6) traumatic brain injury patients for each age range with $p$-value equal to 0.0001 . Cut-off values of $\mathrm{TBI}$ patients according to ROC curves plotted for mild and severe head trauma according to each age group were 4.40 $\mathrm{mm}(66.7 \%$ sensitivity, $95.4 \%$ specificity) in the $0-3$ age range, $4.45 \mathrm{~mm}$ ( $100 \%$ sensitivity, $87.7 \%$ specificity), in the 3-6 age range $4.25 \mathrm{~mm}$ (100\% sensitivity, $81.2 \%$ specificity) in the 6-12 age range, $4.45 \mathrm{~mm}$ ( $100 \%$ sensitivity, $91 \%$ specificity) in the $12-18$ age range, respectively (Table 2 , Fig. 3 ).

\section{DISCUSSION}

CT is the most preferred imaging modality in cases of severe head trauma. It is fast and easily accessible in most of the centers. Besides, it helps to determine the severity of the trauma and necessity for surgical intervention. ${ }^{[3,4]}$ RCTS system is mainly developed upon adult patients, and data on this system in children are less well documented. ${ }^{[1,3,5]}$ When com-
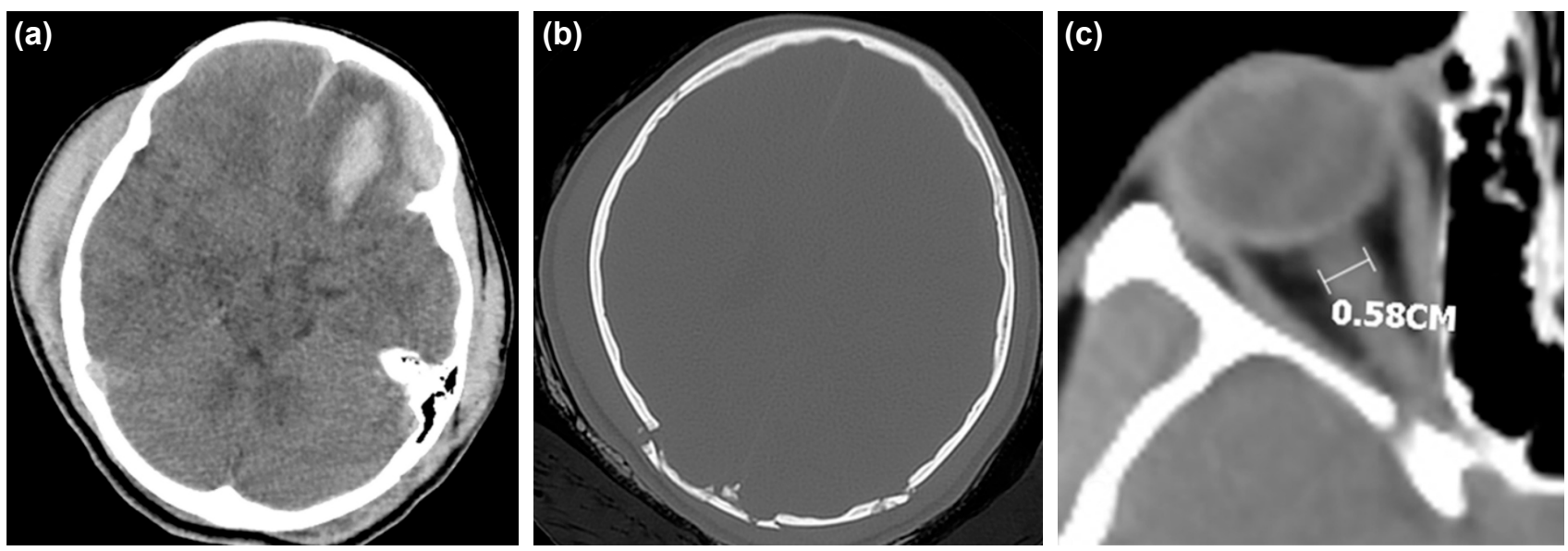

Figure 1. A 15 year old male patient after a traffic accident, RBTS 5; Intraparenchymal subdural-subraracnoid haemorrhage areas in left frontobasal and bilateral cephal hematoma, slight shift in midline structures, effacement in basal cisterns (a), fragmented fractures in parieto-occipital bone (b) increase of ONSD $(5.8 \mathrm{~mm})$ (c).
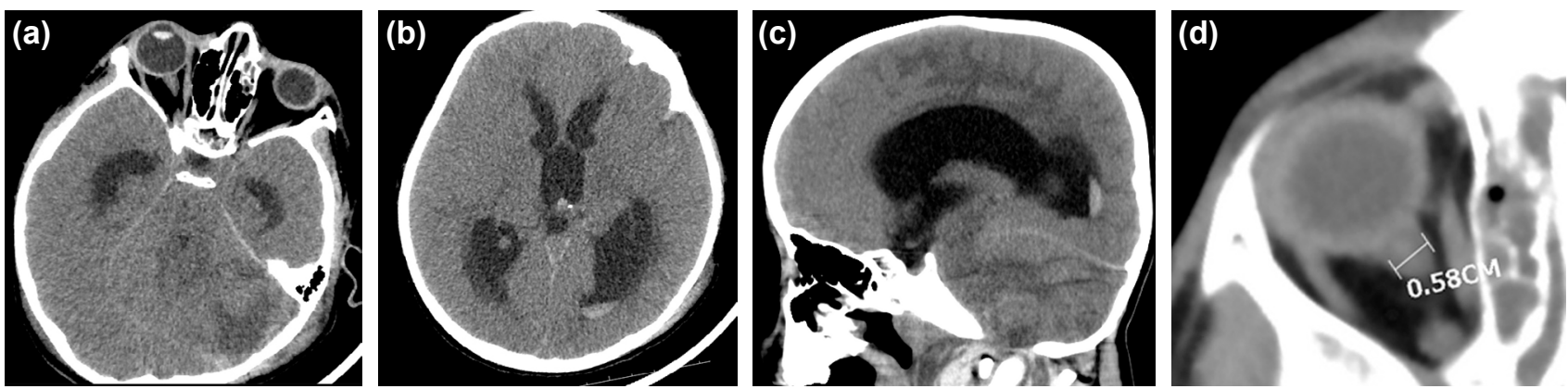

Figure 2. A 6 year old male patient after falling from high, RBTS 6; Subarachnoid and ventricular hemorrhage (a, b), effacement in basal cisterns (a) and dilatation of ventricules (b) blurring on white-gray matter separation $(\mathbf{a}, \mathbf{b})$ in both cerebral hemispheres, cervical dislocation (c), in-crease of ONSD $(5.8 \mathrm{~mm})(\mathbf{d})$. 
Table 2. Cut-off values of ONSDs concerning brain edema in patients with high scores

\begin{tabular}{lccccc}
\hline & AUC & Cut-off value $(\mathbf{m m})$ & Sensitivity & Specificity & p \\
\hline $0-3$ years & 0.81 & 4.40 & 66.7 & 95.4 & 0.0001 \\
$3-6$ years & 0.95 & 4.45 & 100 & 87.7 & 0.0001 \\
6-12 years & 0.96 & 4.25 & 100 & 81.2 & 0.0001 \\
12-18 years & 0.95 & 4.45 & 100 & 91 & 0.0001 \\
\hline
\end{tabular}

AUC: Area under curve; ONSD: Optic nerve sheath diameter

pared to adults, pediatric patients have lower survival rates in higher scores and higher survival rates in lower scores, but it can still be used in risk calculation in severe pediatric head trauma. ${ }^{[5]}$

Raised ICP is associated with secondary brain damage and poor prognosis after traumatic injury. ${ }^{[8]}$ Especially in pediatric population, clinical symptoms of raised ICP are less reliable, and clinicians should be more vigilant in this regard. Symptoms and imaging findings may differ according to age.
[7] Previous studies have shown that CT findings are sometimes inadequate in determining brain edema, which can be fatal if not been treated early. ${ }^{\left[{ }^{\prime I}\right]}$ According to Hirsch et al.' ${ }^{\left[{ }^{[1]}\right]}$ study, the extra-axial distance is larger in pediatric head and unlike the adult brain, the ICP increases after filling of this compensatory distance in pediatric brains. Findings, such as narrowing of CSF distances, a decrease of brain parenchyma density, midline shifts that we can evaluate by radiologically, are reflections of very high ICP values. Unfortunately, these traditional CT findings are inadequate for identification of
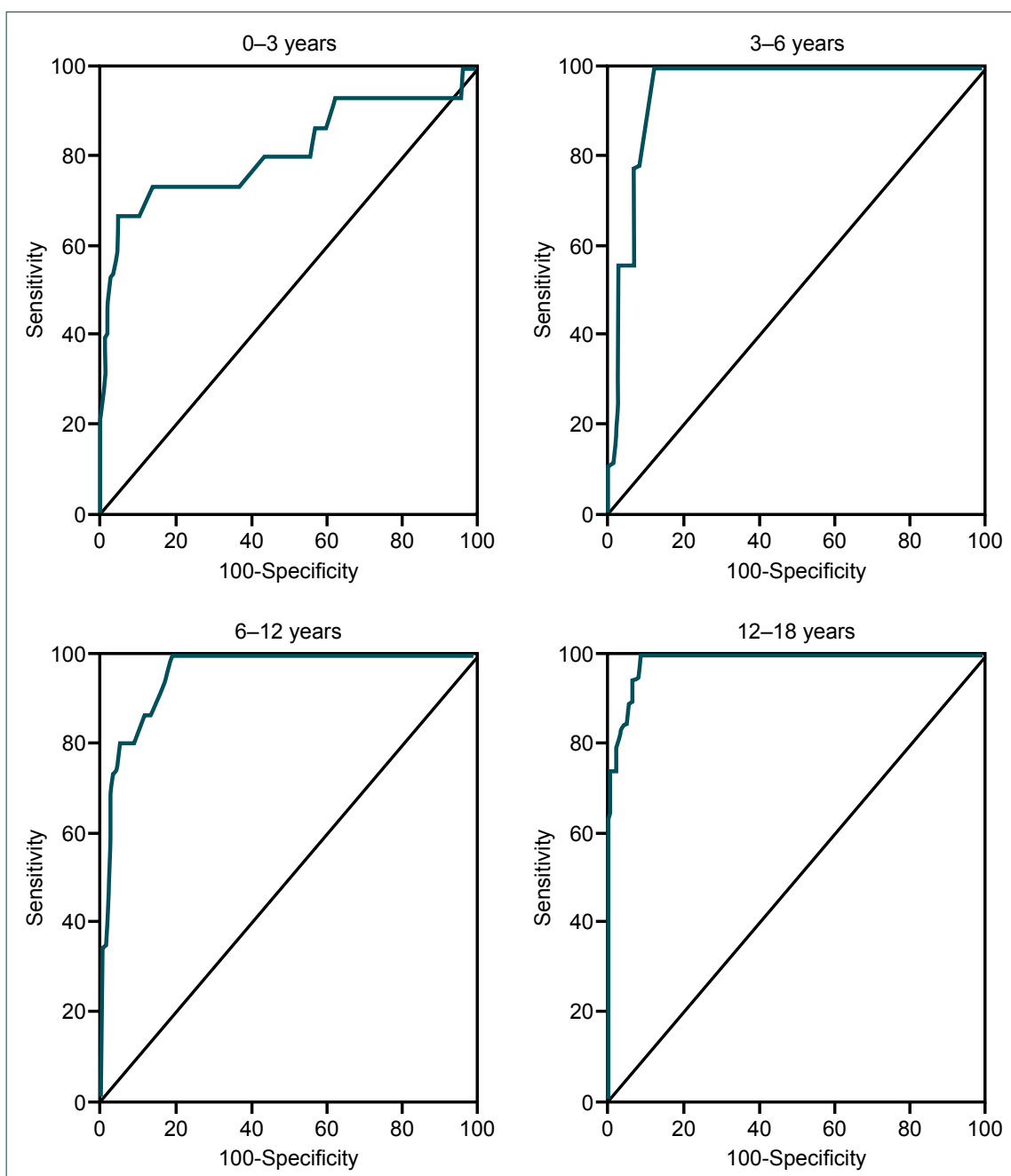

Figure 3. ROC analysis for the relationship between high RCTS (4-5-6) and ONSD for all age groups. 
Table 3. Characteristics of the ONSD studies in pediatric population

\begin{tabular}{|c|c|c|c|c|c|c|}
\hline Study, year & $\begin{array}{l}\text { Used } \\
\text { modality }\end{array}$ & Measurement & Study group & Mean age & Results & Cut-off value \\
\hline $\begin{array}{l}\text { Helmke K et al., } \\
1996^{[8]}\end{array}$ & USG & $\begin{array}{l}3 \mathrm{~mm} \text { posterior } \\
\text { to papilla }\end{array}$ & $\begin{array}{l}\text { I } 3 \text { healthy } \\
\text { children } \\
24 \text { children } \\
\text { with in-creased } \\
\text { ICP }\end{array}$ & $\begin{array}{l}4.8 \text { years } \\
\text { (range two } \\
\text { months to } \\
18 \text { years) }\end{array}$ & $\begin{array}{l}\text { For control group: } \\
\text { ONSD (avg) } 3 \mathrm{~mm} \\
\text { For patient group: } \\
\text { ONSD (avg) } 5.3 \mathrm{~mm}\end{array}$ & $\begin{array}{l}<4 \text { years } 4 \mathrm{~mm} \\
>4 \text { years } 5 \mathrm{~mm}\end{array}$ \\
\hline $\begin{array}{l}\text { Ballantyne et al., } \\
1999^{[26]}\end{array}$ & USG & $\begin{array}{l}3 \mathrm{~mm} \text { posterior } \\
\text { to papilla }\end{array}$ & $\begin{array}{l}\text { I02 children } \\
\text { with non- } \\
\text { neurological } \\
\text { disease }\end{array}$ & $<15$ years & $\begin{array}{l}\text { 0-2 month } \\
\text { ONSD (avg.) } 2.7 \mathrm{~mm} \\
\text { 2-3 month ONSD (avg.) } 2.95 \mathrm{~mm} \\
\text { 3-12 month ONSD (avg.) } 3.21 \mathrm{~mm} \\
\text { I-2 year ONSD (avg.) } 2.99 \mathrm{~mm} \\
\text { 2-3 year ONSD (avg.) } 3.03 \mathrm{~mm} \\
\text { 3-4 year ONSD (avg.) } 3.15 \mathrm{~mm} \\
\text { 4-5 year ONSD (avg.) } 3.23 \mathrm{~mm} \\
\text { 5-10 year ONSD (avg.) } 2.98 \mathrm{~mm} \\
\text { I0-15 year ONSD (avg.) } 3.26 \mathrm{~mm}\end{array}$ & NA \\
\hline $\begin{array}{l}\text { Malayeri et al., } \\
2004^{[28]}\end{array}$ & USG & $\begin{array}{l}3 \mathrm{~mm} \text { posterior } \\
\text { to papilla }\end{array}$ & $\begin{array}{l}78 \text { healthy } \\
\text { children } \\
78 \text { children } \\
\text { with increased } \\
\text { ICP }\end{array}$ & $\begin{array}{l}\text { For patient } \\
\text { group: } \\
6.9 \text { years } \\
\text { (range two } \\
\text { weeks to } \\
17 \text { years } \\
\text { For control } \\
\text { group: } \\
6.8 \text { years } \\
\text { (range five } \\
\text { weeks to } \\
16.5 \text { years }\end{array}$ & $\begin{array}{l}\text { For patient group: } \\
<4 \text { yr ONSD (avg) } 5.55 \mathrm{~mm} \\
>4 \mathrm{yr} \text { ONSD (avg) } 5.68 \mathrm{~mm} \\
\text { For control group: } \\
<4 \mathrm{yr} \text { ONSD (avg) } 3 \mathrm{~mm} \\
>4 \mathrm{yr} \text { ONSD (avg) } 3.60 \mathrm{~mm}\end{array}$ & NA \\
\hline $\begin{array}{l}\text { Korber et al., } \\
2005^{[27]}\end{array}$ & USG & $\begin{array}{l}3 \mathrm{~mm} \text { posterior } \\
\text { to papilla }\end{array}$ & $\begin{array}{l}466 \text { healthy } \\
\text { children } \\
\text { I } 7 \text { children } \\
\text { with increased } \\
\text { ICP }\end{array}$ & $\begin{array}{l}7.5 \text { years } \\
\text { (range from } \\
\text { four days to } \\
24 \text { years) }\end{array}$ & $\begin{array}{l}\text { For control group: } \\
\text { ONSD (avg) } 3.4 \mathrm{~mm} \\
\text { For patient group: } \\
\text { ONSD (avg) } 5.6 \mathrm{~mm}\end{array}$ & $4.5 \mathrm{~mm}$ \\
\hline $\begin{array}{l}\text { Beare et al., } \\
2008^{[12]}\end{array}$ & USG & $\begin{array}{l}3 \mathrm{~mm} \text { posterior } \\
\text { to papilla }\end{array}$ & $\begin{array}{l}30 \text { healthy } \\
\text { children } \\
21 \text { children } \\
\text { with } \\
\text { neurological } \\
\text { disease }\end{array}$ & $\begin{array}{l}\text { For patient } \\
\text { group: } \\
5.7 \text { years } \\
\text { For control } \\
\text { group: } \\
2.7 \text { years }\end{array}$ & $\begin{array}{l}\text { For patient group: } \\
\text { ONSD (avg) } 5.4 \mathrm{~mm} \\
\text { For control group: } \\
\text { ONSD (avg) } 3.6 \mathrm{~mm}\end{array}$ & $\begin{array}{l}4.5 \mathrm{~mm} \\
\text { (sensitivity of } \\
100 \% \text { and } \\
\text { specificity } \\
\text { of } 86 \% \text { ) }\end{array}$ \\
\hline $\begin{array}{l}\text { Le et al., } \\
2009^{[29]}\end{array}$ & USG & $\begin{array}{l}3 \mathrm{~mm} \text { posterior } \\
\text { to papilla }\end{array}$ & $\begin{array}{l}64 \text { children } \\
\text { with increased } \\
\text { ICP }\end{array}$ & $<14$ years & NA & $\begin{array}{l}<1 \text { year } 4.0 \mathrm{~mm} \\
>1 \text { year } 4.5 \mathrm{~mm} \\
\text { (sensitivity of } \\
83 \% \text {, specificity } \\
\text { of } 38 \% \text { ) }\end{array}$ \\
\hline $\begin{array}{l}\text { Steinborn et al., } \\
\left.20\right|^{[30]}\end{array}$ & $\begin{array}{l}\text { USG and } \\
\text { MR }\end{array}$ & $\begin{array}{l}3 \mathrm{~mm} \text { posterior } \\
\text { to papilla }\end{array}$ & $\begin{array}{l}65 \text { children } \\
\text { with various } \\
\text { disease }\end{array}$ & II.3 years & $\begin{array}{l}\text { For USG group: } \\
\text { ONSD (avg) } 5.86 \mathrm{~mm} \\
\text { For MR group: } \\
\text { ONSD (avg) } 5.86 \mathrm{~mm}\end{array}$ & NA \\
\hline
\end{tabular}


Table 3. Characteristics of the ONSD studies in pediatric population (continuation)

\begin{tabular}{|c|c|c|c|c|c|c|}
\hline Study, year & $\begin{array}{l}\text { Used } \\
\text { modality }\end{array}$ & Measurement & Study group & Mean age & Results & Cut-off value \\
\hline $\begin{array}{l}\text { Shofty et al., } \\
2012^{[13]}\end{array}$ & MRI & $\begin{array}{l}10 \mathrm{~mm} \text { anterior } \\
\text { to the optic } \\
\text { foramina }\end{array}$ & $\begin{array}{l}86 \text { healthy } \\
\text { children } \\
29 \text { children } \\
\text { with idiopatic } \\
\text { intracranial } \\
\text { hypertension }\end{array}$ & $\begin{array}{l}<18 \text { years } \\
\text { (range from } \\
\text { four months } \\
\text { to } 17 \text { years) }\end{array}$ & $\begin{array}{l}\text { For control group: } \\
\text { 0-3 yr ONSD (avg.) } 3.1 \mathrm{~mm} \\
\text { 3-6 yr ONSD (avg.) } 3.41 \mathrm{~mm} \\
\text { 6-12 yr ONSD (avg.) } 3.55 \mathrm{~mm} \\
\text { I2-18 yr ONSD (avg.) } 3.56 \mathrm{~mm} \\
\text { For patient group: } \\
\text { 0-3 yr ONSD (avg.) } 4.35 \mathrm{~mm} \\
\text { 3-6 yr ONSD (avg.) } 4.37 \mathrm{~mm} \\
\text { 6-12 yr ONSD (avg.) } 4.25 \mathrm{~mm} \\
\text { I2-18 yr ONSD (avg.) } 4.69 \mathrm{~mm}\end{array}$ & NA \\
\hline $\begin{array}{l}\text { Agrawal et al., } \\
2012^{[31]}\end{array}$ & USG & $\begin{array}{l}3 \mathrm{~mm} \text { posterior } \\
\text { to papilla }\end{array}$ & $\begin{array}{l}\text { II ICP- } \\
\text { monitored } \\
\text { children }\end{array}$ & $\begin{array}{l}9.2 \text { years } \\
\text { (range from } \\
\text { two years } \\
\text { to } 15 \text { years) }\end{array}$ & $\begin{array}{l}\text { For patient group: } \\
\text { <I years ONSD (avg) } 4.0 \mathrm{~mm} \\
>\text { I years ONSD (avg) } 4.5 \mathrm{~mm}\end{array}$ & NA \\
\hline $\begin{array}{l}\text { Young et al., } \\
2016^{[18]}\end{array}$ & CT & $\begin{array}{l}3 \mathrm{~mm} \text { posterior } \\
\text { to papilla }\end{array}$ & $\begin{array}{l}36 \mathrm{TBI} \\
\text { patients }\end{array}$ & 8.2 years & $\begin{array}{l}\text { For patient group: } \\
\text { Right ONSD (avg) } 5.6+2.5 \mathrm{~mm} \\
\text { Left ONSD (avg) } 5.9+3.2 \mathrm{~mm}\end{array}$ & $\begin{array}{l}6.1 \mathrm{~mm} \\
\text { (sensitivity } 77 \% \text {, } \\
\text { specificity } 91 \% \text { ) } \\
4.9 \mathrm{~mm}(100 \% \\
\text { sensitivity, } 26 \% \\
\text { specificity) }\end{array}$ \\
\hline $\begin{array}{l}\text { Steinborn et al., } \\
2015^{[32]}\end{array}$ & $\begin{array}{l}\text { USG and } \\
\text { MR }\end{array}$ & $\begin{array}{l}3 \mathrm{~mm} \text { posterior } \\
\text { to papilla }\end{array}$ & $\begin{array}{l}\text { For USG } \\
99 \text { healthy } \\
\text { children } \\
\text { For MR } \\
59 \text { healthy } \\
\text { children }\end{array}$ & $\begin{array}{l}\text { For USG: } \\
12 \text { years } \\
\text { (range from } \\
5.6 \text { years to } \\
18.6 \text { years) } \\
\text { For MR: } \\
12,3 \text { years } \\
\text { (range from } \\
5.1 \text { years to } \\
\text { I7.4 years) }\end{array}$ & $\begin{array}{l}\text { For USG group: } \\
\text { ONSD (avg) } 5.75 \mathrm{~mm} \\
\text { For MR group: } \\
\text { ONSD (avg) } 5.69 \mathrm{~mm}\end{array}$ & NA \\
\hline $\begin{array}{l}\text { Padayachy et al., } \\
2015^{[15]}\end{array}$ & USG & $\begin{array}{l}3 \mathrm{~mm} \text { posterior } \\
\text { to papilla }\end{array}$ & $\begin{array}{l}\text { I74 ICP- } \\
\text { monitored } \\
\text { patients }\end{array}$ & 36 months & $\begin{array}{l}\text { For ICP <20 mmHg: } \\
\text { ONSD (avg) } 4.8 \mathrm{~mm} \\
\text { For ICP } \geq 20 \mathrm{mmHg} \text { : } \\
>\text { I years ONSD (avg) } \\
5.92 \mathrm{~mm}\end{array}$ & $\begin{array}{l}<1 \text { years } 5.16 \\
\mathrm{~mm} \text { (sensitivity } \\
\text { of } 80 \% \text {, } \\
\text { specificity of } \\
76.1 \% \text { ) } \\
>1 \text { years } \\
5.75 \mathrm{~mm} \\
\text { (sensitivity of } \\
85.9 \% \text {, specificity } \\
\text { of } 70.4 \% \text { ) } \\
1-4 \text { years } \\
5.92 \mathrm{~mm} \\
>4 \text { years } \\
5.70 \mathrm{~mm}\end{array}$ \\
\hline $\begin{array}{l}\text { Irazuzta et al., } \\
2015^{[33]}\end{array}$ & USG & $\begin{array}{l}3 \mathrm{~mm} \text { posterior } \\
\text { to papilla }\end{array}$ & $\begin{array}{l}\text { I } 3 \text { children } \\
\text { with idiopatic } \\
\text { intracranial } \\
\text { hypertension }\end{array}$ & $\begin{array}{l}14 \text { years } \\
\text { (range from } \\
12 \text { years to } \\
18 \text { years) }\end{array}$ & $\begin{array}{l}\text { For patient group: } \\
\text { ONSD (avg) } 5 \mathrm{~mm}\end{array}$ & $\begin{array}{l}4.5 \mathrm{~mm} \\
\text { (sensitivity of } \\
100 \% \text {, specificity } \\
\text { of } 100 \% \text { ) }\end{array}$ \\
\hline
\end{tabular}


Table 3. Characteristics of the ONSD studies in pediatric population (continuation)

\begin{tabular}{lllllll}
\hline Study, year & $\begin{array}{l}\text { Used } \\
\text { modality }\end{array}$ & Measurement & Study group & Mean age & Results & Cut-off value \\
\hline $\begin{array}{llllll}\text { Padayachy et al., } \\
2016^{[16]}\end{array}$ & USG & $\begin{array}{l}3 \mathrm{~mm} \text { posterior } \\
\text { to papilla }\end{array}$ & $\begin{array}{l}\text { I74 ICP- } \\
\text { monitored } \\
\text { patients }\end{array}$ & $\begin{array}{l}\text { Mean age } \\
36 \text { months } \\
<14 \text { years }\end{array}$ & ONSD (avg) $5.56 \mathrm{~mm}$ & $\begin{array}{l}5.5 \mathrm{~mm} \\
\text { (sensitivity of } \\
93.2 \% \text { and } \\
\text { specificity of } \\
\end{array}$ \\
& & & & & $74 \%)$
\end{tabular}

brain edema, especially in pediatric patients. Therefore, some additional parameters should be considered to reflect brain edema in addition to RCTS.

The optic nerve is an extension of the central nervous system and is covered with dura mater. Thus, CSF fills the distance between the dura mater and optic nerve; any change of pressure in the intracranial area will directly reflect the ONSD. Correlation between ONSD and ICP has been shown many times in both adult and pediatric studies. ${ }^{[12,14-16,20,21]}$ Many pathologies, such as diabetic ketoacidosis, anesthetic drug usage, hydrocephalus, could increase the ONSD by increasing the ICP. ${ }^{[22,23]}$ Correlations between RCTS and ONSD have been shown in a previous study for adult traumatic brain injury, and measures above $5.8 \mathrm{~mm}$ for ONSD have been determined for severe TBI for adults. ${ }^{[24]}$ However, to our knowledge, there is no study yet for the pediatric head injury that comparing RCTS and ONSD. A summary of the studies with the pediatric population on ONSD is presented in Table $3^{[12,13,15,16,18,25-32]}$

Values determined by USG in normal child populations were mentioned previously by Ballantyne et al.,"26] in 1999 and results were quite similar to our result that between $3,6 \mathrm{~mm}$ and $4 \mathrm{~mm}$. Shofty et al. ${ }^{[13]}$ used MRI for measurement in their study and their results for normal brains were a bit lower and for patient group, their results a bit higher than our results. However, their patients' group consisted of 29 patients with idiopathic intracranial hypertension (IIH). The perioptic subarachnoid space distention is one of the diagnostic features of $\mathrm{IIH}$. This may be the reason for the difference in patient groups. We noticed that ONSD shows a rapid increase with age and draws a plate by the age of six. This finding is compatible with the study of Shofty et al. ${ }^{[13]}$ and Ballantyne et al. ${ }^{[26]}$

Although the cut-off values that reflecting the brain edema in some studies indicated in Table 3 showed higher values than our study. In the literature, previous studies have reported that sedation could increase ICP values. ${ }^{[15,16]}$ Most of these studies were conducted with children under sedation in intensive care units and used an ICP catheter inserted into the ventricle as a reference with mean ONSD values between $4 \mathrm{~mm}$ and $5.9 \mathrm{~mm}$. Even some of these children were already undergone a surgical operation before. ${ }^{[13,15,25,27-29,31]}$ We think these factors may have caused their cut-off values to be high. In our study, we compared severe traumatic brain injury (score 4-5-6) for reference and according to the other studies, our study has the largest patient population. Cut-off values in studies of Le et al., ${ }^{[29]}$ Körber et al., ${ }^{[27]}$ Beare et al., ${ }^{[12]}$ Irazuzta et al. ${ }^{[33]}$ and Marchese et al., ${ }^{[34]}$ are quiet similar with ours. Young et al. ${ }^{[18]}$ who had a small patient population compared to us, found no correlation between Marshall CT scores and ONSD in their study with pediatric brain injury patients. We found a positive correlation between ONSD and high RCTSs for pediatric patients like Sekhon et al. whose study showed a correlation between ONSD and RCTSs in the adult patient group. ${ }^{[35]}$

We believe that this study provides useful information and can help in the understanding of the prognostic role of ONSD in traumatic brain injury. We emphasize that, in evaluating the initial CT images, ONSD should be assessed, as well as the other parameters of the RCTS. Even ONSD measurement may be more objective and useful evidence of brain injury than other conventional CT findings. CT cannot be used for instantaneous ICP measurement because of radiation exposure and mobility difficulties of intensive care patients. However, almost every patient with a severe traumatic head injury has at least one initial head CT image and evaluating ONSD upon CT image is more objective and simple compared to other methods. CT can be very useful in the investigation of brain edema and arrangement of treatment in cases where catheter placement is contraindicated.

There are some limitations to our study. Inter and intraobserver variability was not evaluated in our study. Pathologies that may affect optic nerve size, such as optic atrophy and thyroid ophthalmopathy, were ignored if $\mathrm{CT}$ findings were 
not apparent. The optic nerve is not a perfectly cylindrical structure and the images were evaluated only in the axial plane, which may cause the differences in the measurements. Because of the necessity of the multidisciplinary approach, we did not consider shaken baby syndrome.

\section{Conclusion}

CT examination is the easiest and fastest radiological imaging method that can be used in head trauma patients in most centers. In our study, the relationship between ONSD and severe traumatic brain injury in CT was demonstrated, reference values of ONSD according to age groups in severe head trauma and age-related cut-off values for brain edema in severe head trauma have been determined. In addition to the diagnostic assessment of the first CT scan, ONSD measurement may be useful in early diagnosis and treatment of brain edema.

Ethics Committee Approval: Approved by the local ethics committee.

Peer-review: Internally peer-reviewed.

Authorship Contributions: Concept: Y.K.; Design: N.Ü.T.; Supervision: Y.K., T.K.; Materials: D.E.T.Ş., E.Ü., O.Y.; Data: S.T.; Analysis: N.Ü.T.; Literature search: O.Y.; Writing: Y.K.; Critical revision: Y.K., N.Ü.T.

Conflict of Interest: None declared.

Financial Disclosure: The autors declared that this study has received no financial support.

\section{REFERENCES}

1. Alexiou GA, Sfakianos G, Prodromou N. Pediatric head trauma.J Emerg Trauma Shock 2011;4:403-8. [CrossRef]

2. Adelson PD, Pineda J, Bell MJ, Abend NS, Berger RP, Giza CC, et al; Pediatric TBI Demographics and Clinical Assessment Working Group. Common data elements for pediatric traumatic brain injury: recommendations from the working group on demographics and clinical assessment. J Neurotrauma 2012;29:639-53. [CrossRef]

3. Tasker RC. CT characteristics, risk stratification, and prediction models in traumatic brain injury. Pediatr Crit Care Med 2014;15:569-70. [CrossRef]

4. Waqas M, Bakhshi SK, Shamim MS, Anwar S. Radiological prognostication in patients with head trauma requiring decompressive craniectomy: Analysis of optic nerve sheath diameter and Rotterdam CT Scoring System. J Neuroradiol 2016;43:25-30. [CrossRef]

5. Liesemer K, Riva-Cambrin J, Bennett KS, Bratton SL, Tran H, Metzger RR, et al. Use of Rotterdam CT scores for mortality risk stratifcation in children with traumatic brain injury. Pediatr Crit Care Med 2014;15:554-62. [CrossRef]

6. Sarkar K, Keachie K, Nguyen U, Muizelaar JP, Zwienenberg-Lee M, Shahlaie K. Computed tomography characteristics in pediatric versus adult traumatic brain injury. J Neurosurg Pediatr 2014;13:307-14. [CrossRef]

7. Singh N, Singhal A. Challenges in minor TBI and indications for head CT in pediatric TBI-an update. Child's Nervous System : Chns : Official Journal of the International Society for Pediatric Neurosurgery 2017;33:1677-81. [CrossRef]

8. Maissan IM, Dirven PJ, Haitsma IK, Hoeks SE, Gommers D, Stolker
RJ. Ultrasonographic measured optic nerve sheath diameter as an accurate and quick monitor for changes in intracranial pressure. J Neurosurg 2015;123:743-7. [CrossRef]

9. Narayan V, Mohammed N, Savardekar AR, Patra DP, Notarianni C, Nanda A. Noninvasive Intracranial Pressure Monitoring for Severe Traumatic Brain Injury in Children: A Concise Update on Current Methods. World Neurosurg 2018;114:293-300. [CrossRef]

10. Aduayi OS, Asaleye CM, Adetiloye VA, Komolafe EO, Aduayi VA. Optic nerve sonography: A noninvasive means of detecting raised intracranial pressure in a resource-limited setting. J Neurosci Rural Pract 2015;6:563-7. [CrossRef]

11. Hirsch W, Beck R, Behrmann C, Schobess A, Spielmann RP. Reliability of cranial CT versus intracerebral pressure measurement for the evaluation of generalised cerebral oedema in children. Pediatr Radiol 2000;30:439-43. [CrossRef]

12. Beare NA, Kampondeni S, Glover SJ, Molyneux E, Taylor TE, Harding $\mathrm{SP}$, et al. Detection of raised intracranial pressure by ultrasound measurement of optic nerve sheath diameter in African children. Trop Med Int Health 2008;13:1400-4. [CrossRef]

13. Shofty B, Ben-Sira L, Constantini S, Freedman S, Kesler A. Optic nerve sheath diameter on MR imaging: establishment of norms and comparison of pediatric patients with idiopathic intracranial hypertension with healthy controls. AJNR Am J Neuroradiol 2012;33:366-9. [CrossRef]

14. Legrand A, Jeanjean P, Delanghe F, Peltier J, Lecat B, Dupont H. Estimation of optic nerve sheath diameter on an initial brain computed tomography scan can contribute prognostic information in traumatic brain injury patients. Crit Care 2013;17:R61. [CrossRef]

15. Padayachy LC, Padayachy V, Galal U, Gray R, Fieggen AG. The relationship between transorbital ultrasound measurement of the optic nerve sheath diameter (ONSD) and invasively measured ICP in children : Part I: repeatability, observer variability and general analysis. Childs Nerv Syst 2016;32:1769-78. [CrossRef]

16. Padayachy V. Transorbital measurement of the optic nerve sheath diameter (ONSD) as a screening tool for raised intracranial pressure (ICP) in an acute care setting in children. University of Cape Town, March 3rd, 2016.

17. Vaiman M, Sigal T, Kimiagar I, Bekerman I. Intracranial Pressure Assessment in Traumatic Head Injury with Hemorrhage Via Optic Nerve Sheath Diameter. J Neurotrauma 2016;33:2147-53. [CrossRef]

18. Young AM, Guilfoyle MR, Donnelly J, Scoffings D, Fernandes H, Garnett $M$, et al. Correlating optic nerve sheath diameter with opening intracranial pressure in pediatric traumatic brain injury. Pediatr Res 2017;81:443-7. [CrossRef]

19. Hukkelhoven CW, Steyerberg EW, Habbema JD, Farace E, Marmarou A, Murray GD, et al. Predicting outcome after traumatic brain injury: development and validation of a prognostic score based on admission characteristics. J Neurotrauma 2005;22:1025-39. [CrossRef]

20. Tayal VS, Neulander M, Norton HJ, Foster T, Saunders T, Blaivas M. Emergency department sonographic measurement of optic nerve sheath diameter to detect findings of increased intracranial pressure in adult head injury patients. Ann Emerg Med 2007;49:508-14. [CrossRef]

21. Yesilaras M, Kilic TY, Yesilaras S, Atilla OD, Öncel D, Çamlar M. The diagnostic and prognostic value of the optic nerve sheath diameter on $\mathrm{CT}$ for diagnosis spontaneous subarachnoid hemorrhage. Am J Emerg Med 2017;35:1408-13. [CrossRef]

22. Choi SH, Min KT, Park EK, Kim MS, Jung JH, Kim H. Ultrasonography of the optic nerve sheath to assess intracranial pressure changes after ventriculo-peritoneal shunt surgery in children with hydrocephalus: a prospective observational study. Anaesthesia 2015;70:1268-73. [CrossRef] 
23. Min JY, Lee JR, Oh JT, Kim MS, Jun EK, An J. Ultrasonographic assessment of optic nerve sheath diameter during pediatric laparoscopy. Ultrasound Med Biol 2015;41:1241-6. [CrossRef]

24. Das SK, Shetty SP, Sen KK. A Novel Triage Tool: Optic Nerve Sheath Diameter in Traumatic Brain Injury and its Correlation to Rotterdam Computed Tomography (CT) Scoring. Pol J Radiol 2017;82:240-3. [CrossRef]

25. Helmke K, Hansen HC. Fundamentals of transorbital sonographic evaluation of optic nerve sheath expansion under intracranial hypertension. I. Experimental study. Pediatr Radiol 1996;26:701-5. [CrossRef]

26. Ballantyne J, Hollman AS, Hamilton R, Bradnam MS, Carachi R, Young DG, et al. Transorbital optic nerve sheath ultrasonography in normal children. Clin Radiol 1999;54:740-2. [CrossRef]

27. Körber F, Scharf M, Moritz J, Dralle D, Alzen G. Sonography of the optical nerve-experience in 483 children. [Article in German]. Rofo 2005;177:229-35. [CrossRef]

28. Malayeri AA, Bavarian S, Mehdizadeh M. Sonographic evaluation of optic nerve diameter in children with raised intracranial pressure. J Ultrasound Med 2005;24:143-7. [CrossRef]

29. Le A, Hoehn ME, Smith ME, Spentzas T, Schlappy D, Pershad J. Bedside sonographic measurement of optic nerve sheath diameter as a predictor of increased intracranial pressure in children. Ann Emerg Med 2009;53:785-91. [CrossRef]
30. Steinborn M, Fiegler J, Ruedisser K, Hapfelmeier A, Denne C, Macdonald E, et al. Measurement of the Optic Nerve Sheath Diameter in Children: Comparison Between Transbulbar Sonography and Magnetic Resonance Imaging. Ultraschall Med 2012;33:569-73. [CrossRef]

31. Agrawal S, Brierley J. Optic nerve sheath measurement and raised intracranial pressure in paediatric traumatic brain injury. Eur J Trauma Emerg Surg 2012;38:75-7. [CrossRef]

32. Steinborn M, Friedmann M, Hahn H, Hapfelmeier A, Macdonald E, Warncke K, et al. Normal values for transbulbar sonography and magnetic resonance imaging of the optic nerve sheath diameter (ONSD) in children and adolescents. Ultraschall Med 2015;36:54-8. [CrossRef]

33. Irazuzta JE, Brown ME, Akhtar J. Bedside Optic Nerve Sheath Diameter Assessment in the Identification of Increased Intracranial Pressure in Suspected Idiopathic Intracranial Hypertension. Pediatr Neurol 2016;54:35-8. [CrossRef]

34. Marchese RF, Mistry RD, Binenbaum G, Liu GT, Scarfone RJ, Woodford $\mathrm{AL}$, et al. Identification of Optic Nerve Swelling Using Point-of-Care Ocular Ultrasound in Children. Pediatr Emerg Care 2018;34:531-6.

35. Sekhon MS, McBeth P, Zou J, Qiao L, Kolmodin L, Henderson WR, et al. Association between optic nerve sheath diameter and mortality in patients with severe traumatic brain injury. Neurocrit Care 2014;21:245-52. [CrossRef]

\title{
ORİJINAL ÇALIŞMA - ÖZET
}

\section{Pediatrik beyin hasarında optik sinir kılıf çapı ile Rotterdam bilgisayarlı tomografi skorlama arasındaki korelasyon}

\section{Dr. Yasemin Kayadibi, ${ }^{1}$ Dr. Nazan Ülgen Tekerek, ${ }^{2}$ Dr. Osman Yeşilbaş, ${ }^{2}$ Dr. Serhat Tekerek, Dr. Emel Üre, ${ }^{3}$ Dr. Turgut Kayadibi, ${ }^{4}$ Dr. Deniz Esin Tekcan Şanlı ${ }^{5}$}

\author{
${ }^{1}$ Van Eğitim ve Araştırma Hastanesi, Radyoloji Kliniği, Van \\ ${ }^{2}$ Van Eğitim ve Araştırma Hastanesi, Çocuk Yoğun Bakım Kliniği, Van \\ ${ }^{3}$ Hakkari Devlet Hastanesi, Radyoloji Kliniği, Hakkari \\ ${ }^{4}$ Van Eğitim ve Araştırma Hastanesi, Plastik Cerrahi Kliniği, Van \\ ${ }^{5}$ Kahramanmaraş Necip Fazıl Şehir Hastanesi, Radyoloji Kliniği, Kahramanmaraş
}

AMAÇ: Kafa travması pediatrik hastalarda acil servise en sık başvuru sebebidir. Kafa travmasında kafa içi basıncın (KiB) artması ikincil beyin hasarına neden olmakla birlikte, hastanın tedavisinde önemlidir. Optik sinir klıf çapının (OSKÇ) ölçümü artmış KiB'nin belirlenmesinde kullanılabilir bir yöntemdir. Biz bu çalışmada ciddi kafa travmalı pediatrik olgularda OSKÇ ile prognoz açısından önemli Rotterdam bilgisayarlı tomografi skorlama (RBTS) sistemi arasındaki ilişkiyi araştırmayı hedefledik.

GEREÇ VE YÖNTEM: Ocak 20I7-Nisan 2018 tarihleri arasında 0-18 yaş aralığında hastanemiz acil servisine kafa travması (n=40I) ve kafa travması dışı (konvülziyon, solunum sıkıntıı, baş ağrısı) $(n=255)$ şikayetlerle başvuran, bilgisayatlı tomografı (BT) çekilen toplam 656 hastaların görüntüleri ve tıbbi kayıtları geriye dönük olarak değerlendirildi. Hastaların yaşı, cinsiyeti, geliş şikayeti, travmanın şekli (yüksek enerjili-düşük enerjili) kaydedildi. Kafa travması ile başvuran hastalar, hasta grubu; travma dışı sebeplerle başvuran ve çekilen beyin BT'si normal olarak yorumlanan hastalar kontrol grubu olarak belirlendi. BT bulgularına göre travmatik beyin hasarları Rotterdam kriterlerince skorlandı. Hastalar 0-3 yaş, 3-6 yaş, 6-12 yaş ve I2-18 yaş olarak yaşlarına göre sınıflandırıldı.

BULGULAR: Çalışmamızda pediatrik olgular için OSKÇ’nin yaş aralıklarına göre tomografik referans değerleri belirlendi. Ciddi kafa travmalı hastaların OSKÇ ile kontrol grubu arasında anlamlı farklılık mevcuttu $(p<0.05)$. RBTS ve OSKÇ arasında korelasyon izlenmiş olup ciddi kafa travmasında (scor 4-5-6) kullanılabilecek, yaş aralıklarına göre kestirim değerleri belirlendi.

TARTIŞMA: Çalışmamız pediatrik ciddi kafa travmasınında prognozu belirlemede RBTS sistemine ek olarak artmış KiB'nin gösterilmesinde OSKÇ değerlerinin de kullanılabileceğini göstermiştir. Ayrıca çalışmamızda pediatrik hastalar için OSKÇ'nin tomografik referans değerleri belirlenmiştir. Anahtar sözcükler: Beyin ödemi; kafaiçi basınç; optik sinir kılıf çapı; pediatrik kafa travması; Rotterdam bilgisayarlı tomografi skoru.

Ulus Travma Acil Cerrahi Derg 2020;26(2):2I2-22I doi: 10.14744/tites.2019.94994 